\title{
Small Cell Melanoma
}

\author{
Hyo Sang Song, You Chan Kim \\ Department of Dermatology, Ajou University School of Medicine, Suwon, Korea
}

\section{Dear Editor:}

Small cells can be observed in various neoplasms such as small-cell neuroendocrine carcinoma, lymphoma, neuroblastoma, Ewing's sarcoma, and malignant melanoma. Small-cell melanoma, however, is a very rare type of malignant melanoma ${ }^{1}$. We report a case of malignant melanoma composed mostly of small cells. To our knowledge, this is the first report of such a case in Korea. A 70-year-old female patient was referred to our clinic from a private clinic for an accurate diagnosis of a skin lesion on the right sole. She first recognized the lesion 1 year ago, which seemed to have been increasing in size without any other symptoms. A skin biopsy from the sole was obtained at a private clinic. At the time of her visit, a solitary black patch on sutured skin was noted on her right sole, and irregular brownish to bluish small patches were observed beside the excised area (Fig. 1). The histopathology slide showed a dense aggregation of small cells in the dermis. The cells were small, hyperchromatic, and had scant cytoplasm. On immunohistochemistry, the tumor cells were reactive to $\mathrm{HMB}-45$, and also reactive to S-100 protein and Melan-A. After the lesion was diagnosed as malignant melanoma, the patient was referred to the department of plastic surgery for operation and staging. She was scheduled to undergo surgery 2 months later. During the waiting period, her lesion showed an abruptly enlarged ulcerative mass protruding from the patches. The completely excised mass lesion

Received February 5, 2013, Revised June 24, 2013, Accepted for publication June 25, 2013

Corresponding author: You Chan Kim, Department of Dermatology, Ajou University School of Medicine, 164 WorldCup-ro, Yeongtong-gu, Suwon 443-380, Korea. Tel: 82-31-219-5190, Fax: 82-31-219-5189, E-mail: maychan@ajou.ac.kr

This is an Open Access article distributed under the terms of the Creative Commons Attribution Non-Commercial License (http:// creativecommons.org/licenses/by-nc/3.0) which permits unrestricted non-commercial use, distribution, and reproduction in any medium, provided the original work is properly cited. showed aggregation of dense small cells with vascular invasion into the dermis without lentiginous melanocytic proliferation, whereas the brownish to bluish small patches exhibited lentiginous proliferation of atypical melanocytes (Fig. 2). On computed tomography, metastasis to the liver and bone were noted; her melanoma was diagnosed as stage IV. She was moved to the hematology-oncology department and has since been receiving chemotherapy. The small cell type is a very uncommon subtype, occurring in about $2 \%$ of all malignant melanomas ${ }^{2}$, and manifests as protuberant or ulcerating nodules with aggressive behavior $^{3}$. Its prognosis, however, is not well documented because of its rarity. Histopathologically, small cell melanoma requires differential diagnosis with other small cell neoplasms, including neuroendocrine carcinoma, lymphoblastic lymphoma, neuroblastoma, and Ewing's sarcoma. In our case, the clinical manifestation of black patch on the sole suggested melanoma. Furthermore, lentiginous epidermal involvement of melanocytes, which was observed as a black patch beside the nodule containing the small cells in our case, is not observed in the other

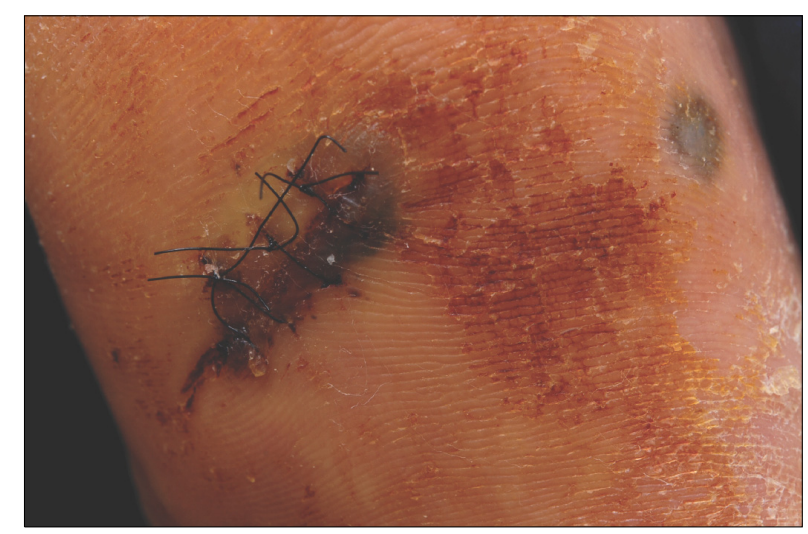

Fig. 1. A solitary black patch on sutured skin and irregular brownish to bluish small patches beside the excised area were observed on the patient's right sole. 

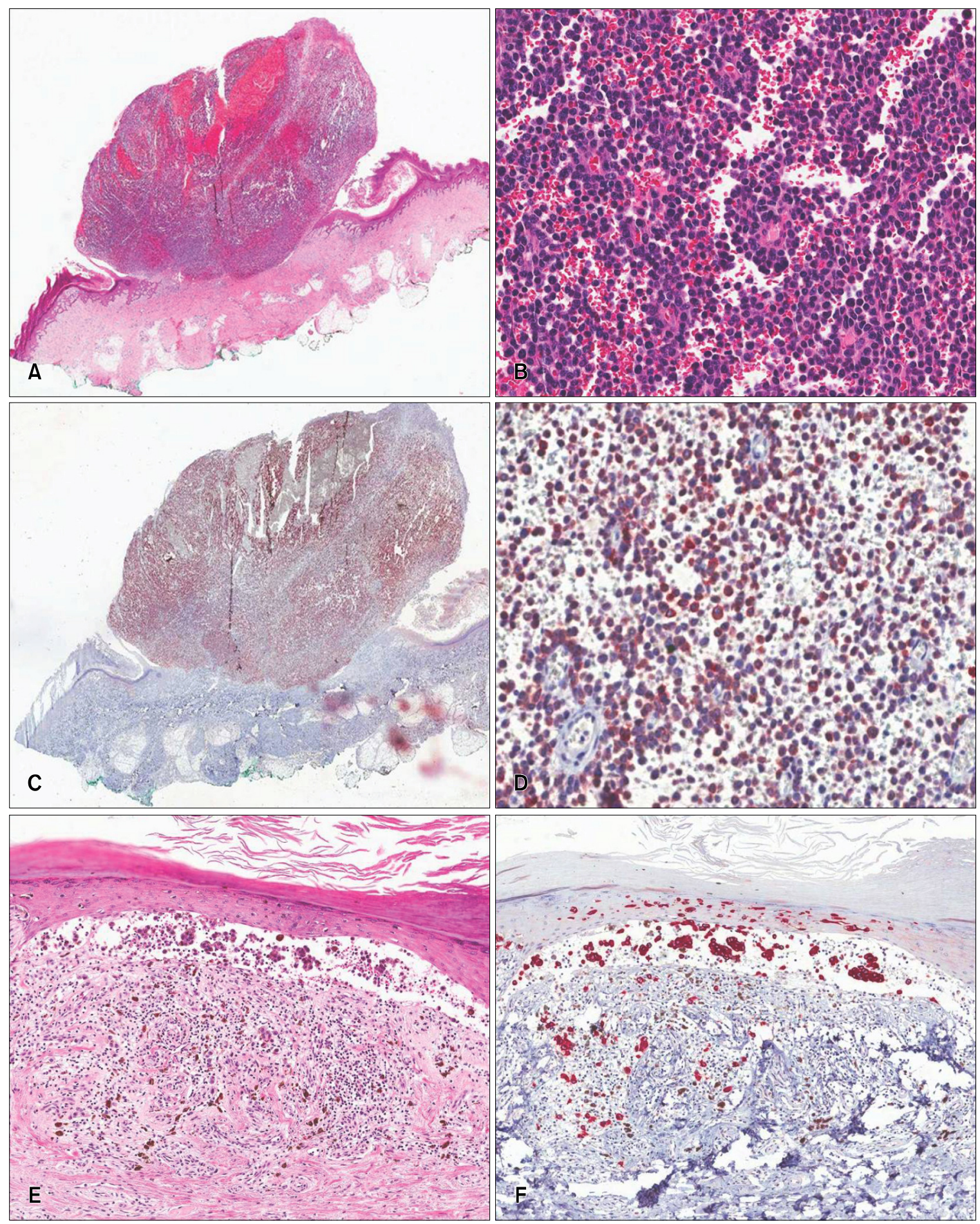

Fig. 2. The excised nodular lesion was composed of small cells. The round small cells were immunoreactive to Melan-A (A $\sim D$ ). Beside the nodular lesion, a black patch with lentiginous proliferation of melanocytes and showing reactivity to Melan-A was observed $(\mathrm{E}, \mathrm{F})$. (A) $\mathrm{H} \& \mathrm{E}, \times 4$; (B) $\mathrm{H} \& \mathrm{E}, \times 200$; (C) immunohistochemical stain, $\times 4$; (D) immunohistochemical stain, $\times 200$; (E) H\&E, $\times 100$; (F) immunohistochemical stain, $\times 100$.

tumor types described above. Although neuroblastoma sometimes stains positive for S-100 protein, positive staining for HMB-45 and Melan-A as well as S-100 protein confirmed the diagnosis of melanoma in our case ${ }^{4}$.
Herein, we report a very rare type of malignant melanoma, small cell melanoma. This case is important because it shows that when aggregation of small cells is observed on histopathology, malignant melanoma should 
be considered in the differential diagnosis so that patients can receive immediate treatment.

\section{REFERENCES}

1. Eyden B, Moss J, Shore I, Banerjee SS. Metastatic small cell malignant melanoma: a case requiring immunoelectronmicroscopy for the demonstration of lattice-deficient melanosomes. Ultrastruct Pathol 2005;29:71-78.
2. Nakhleh RE, Wick MR, Rocamora A, Swanson PE, Dehner LP. Morphologic diversity in malignant melanomas. Am J Clin Pathol 1990;93:731-740.

3. Magro CM, Crowson AN, Mihm MC. Unusual variants of malignant melanoma. Mod Pathol 2006;19 Suppl 2:S41-S70.

4. Lever WF, Elder DE. Lever's histopathology of the skin. 10th ed. Philadelphia: Wolters Kluwer Health/Lippincott Williams \& Wilkins, 2009:xix, 1257.

\title{
Gene-Gene Interaction between LCE and CLEC16A Increases the Risk of Psoriasis in a Chinese Population
}

\author{
Jianbo Wang ${ }^{1, *}$, Yantao Ding ${ }^{1, *}$, Xing Fan ${ }^{1}$, Xianbo Zuo ${ }^{2}$, Wen Wang ${ }^{1}$, Hui Cheng ${ }^{1}$, Ping $\mathrm{Li}^{1}$, \\ Liangdan Sun ${ }^{1,2}$, Sen Yang ${ }^{1,2}$, Xuejun Zhang ${ }^{1,2}$ \\ ${ }^{1}$ Institute of Dermatology, Department of Dermatology, No.1 Hospital, Anhui Medical University, \\ ${ }^{2}$ Key Laboratory of Dermatology, Anhui Medical University, Ministry of Education, Hefei, Anhui, China
}

\section{Dear Editor:}

Psoriasis is a common cutaneous disease characterized by inflammation and abnormal epidermal proliferation. Currently, some inflammatory cells, such as dendritic cells, macrophages, neutrophils, and keratinocytes, and several cytokines are believed to play important roles in the pathogenesis of psoriasis ${ }^{1}$. Our previous genome-wide association study (GWAS) provided convincing evidence

Received November 15, 2012, Revised June 11, 2013, Accepted for publication June 28, 2013

${ }^{*}$ These authors contributed equally to this work.

Corresponding author: Xuejun Zhang, Institute of Dermatology, Anhui Medical University, No. 81, Meishan Road, Hefei, Anhui 230032, China. Tel: 86-551-5161002, Fax: 86-551-5161016, Email: ayzxj@ vip.sina.com.

This is an Open Access article distributed under the terms of the Creative Commons Attribution Non-Commercial License (http:// creativecommons.org/licenses/by-nc/3.0) which permits unrestricted non-commercial use, distribution, and reproduction in any medium, provided the original work is properly cited. for the $L C E$ gene cluster being a susceptibility factor for psoriasis and showed that CLEC16A was significantly associated with development of psoriasis (SNP rs193756, odds ratio $[O R]=0.8, p=0.0004)^{2}$, although $\mathrm{P}_{\mathrm{rs} 193756}$ was found to be $>10^{-8}$. Moreover, CLEC16A has previously been found to be linked to multiple sclerosis, and patients with this gene were at a higher risk of developing psoriasis ${ }^{3}$. The $L C E$ gene cluster encodes epidermal barrier proteins, and perturbation of expression of these genes is associated with psoriasis ${ }^{4}$. Bergboer et al. ${ }^{5}$ found that the expression of $L C E$ proteins was regulated by a combination of proinflammatory cytokines. In fact, CLEC16A is shown to be highly expressed in inflammatory cells such as dendritic cells, macrophages, B-lymphocytes, and natural killer cells ${ }^{6}$. In addition, the interaction between $L C E$ and HLA-C and among the MHC locus, $L C E$, and $I L 12 B$ have also been studied in large samples of diverse ethnic populations ${ }^{7,8}$. Therefore, the postulated common pathway of $L C E$ and CLEC16A between inflammatory response and epidermal barrier prompted us to examine the combined contribu- 